\title{
A review of the gas hydrate distribution offshore Chilean margin
}

\author{
Ivan Vargas-Cordero de la $\mathrm{Cruz}^{1 *}$, Michela Giustiniani ${ }^{2}$, Umberta Tinivella ${ }^{2}$, and Giulia \\ Alessandrini ${ }^{3}$ \\ ${ }^{1}$ Valparaiso, Chile \\ ${ }^{2}$ National Institute of Oceanography and Applied Geophysics - OGS, Borgo Grotta Gigante 42/C, \\ Trieste, Italy \\ ${ }^{3}$ Università di Bologna, Dipartimento di Fisica e Astronomia, Sezione Geofisica, 40127, Bologna, Italy
}

\begin{abstract}
In last decades, the Chilean margin has been extensively investigated to better characterize the complex geological setting through the acquisition of geophysical data and, in particular, seismic lines. The analysis of seismic lines allowed identifying the occurrence of gas hydrates and free gas in many places along the margin. Clearly, the gas hydrate reservoir could be a strategic energy reserve for Chile, but, on the other hand, the dissociated of gas hydrate due to climate change could be an issue to face. Moreover, this region is characterized by large and mega-scale earthquakes that may contribute to gas hydrate dissociation and consequent submarine slides triggering. In this context, Chilean margin should be considered a natural laboratory to study the hydrate system evolution.
\end{abstract}

\section{Introduction}

In last decades, the Chilean margin has been extensively investigated to better characterize the complex geological setting through the acquisition of geophysical data and, in particular, seismic lines. The analysis of seismic lines allowed identifying the occurrence of gas hydrates in many places along the Chilean margin [1-17]. Moreover, their occurrence has also been confirmed by the presence of cold seeps emitting methane at the seafloor (e.g., [18-23]).

Along this margin, the gas hydrate reservoir was perforated for the first time with the ODP Leg 141, located near the Chilean triple junction (i.e. [1,2]). These direct measurements estimated an average concentration of gas hydrate and free gas equal to $18 \%$ and $1 \%$ of volume, respectively $[1,2]$. Similar concentrations have been estimated in other places along this margin through the analysis of the seismic data (e.g., $[9,10,12,14,16,24]$. In fact, the seismic data allow identifying the base of the gas hydrate reservoir because of the presence of a high-amplitude reflector, known as bottom simulating reflector (BSR). This reflector represents the transition from the high seismic velocity characterizing gas hydrate-bearing sediments to the low seismic velocity of sediments containing free gas. In some cases, it is possible to recognize also the base of the free gas, known as Base of free Gas Reflector (BGR). The seismic velocity extracted from

*Corresponding author: lacruzvargas@gmail.com 
seismic data analysis is translate in term of gas hydrate and free concentrations by using theoretical models, such as the Tinivella method $[25,26]$ that was adopted in the review here presented.

Clearly, the gas hydrate reservoir could be a strategic energy reserve for Chile, but, on the other hand, the dissociated of gas hydrate due to climate change could be an issue to face. Moreover, this region is characterized by large and mega-scale earthquakes [27] that may contribute to gas hydrate dissociation and consequent submarine slides triggering. In fact, the geological and tectonic setting of this margin is very complex and manly driven by the interaction between three main plates: Antarctica, Scotia, and South America. In fact, the oceanic plates, Nazca and Antarctica, subduct toward East under the South American plate. The intersection of these three plates is named Fuegian Triple Junction [6], and it is interpreted as a diffuse area of deformation $[28,29]$. In the northern portion, the convergence rate is about $8 \mathrm{~cm} / \mathrm{y}$ [30-36], decreasing toward south, until it reaches a minimum rate of $2 \mathrm{~cm} / \mathrm{y}$ south to the Fuegian Triple Junction [11, 15, 33].

Table 1. Seismic lines reported in this paper.

\begin{tabular}{|c|c|c|}
\hline Seismic line & Location in the margin & Reference \\
\hline RC2901-727 & North & {$[13]$} \\
\hline SO161-44 & North & {$[9]$} \\
\hline SO161-35 & North & {$[14]$} \\
\hline RC2901-731 & North & {$[14]$} \\
\hline SO161-29 & North & {$[13]$} \\
\hline SO161-40 & Centre & {$[12]$} \\
\hline RC2901-734 & Centre & {$[9-10]$} \\
\hline RC2902-790 & South & {$[16]$} \\
\hline
\end{tabular}

\section{Data and methods}

The seismic lines presented in this work (Table 1) were acquired in the frame of following researcher projects:

1) SO161 profiles acquired by the RV SONNE cruise in 2001 in the frame of "Subduction Processes off Chile (SPOC)" project;

2) RC2901 profiles acquired by the RV CONRAD cruise in 1988 in the frame of the project "Mid-Ocean Spreading Ridge" of the ODP Program.

The seismic lines were processed with the following procedure in order to evaluate gas hydrate and free gas concentrations (see details in [9]):

1. Identification of BSR: Processing of the seismic profiles to identify the BSR and BGR, if possible, and selection of portion of seismic lines showing the presence of them.

2. Detection of gas hydrate and free gas: Kirchhoff pre-stack depth migration application to obtain a depth seismic section and a reliable velocity model. For details see [9].

3. Estimation of gas hydrate and free gas concentrations: the difference between velocity model, obtained by pre-stack depth migration, and theoretical velocity curves in absence of gas-phase allows estimating the gas-phase concentrations. Gas hydrate presence is characterized by positive anomalies, while negative anomalies indicate the free gas presence. The theoretical velocity is calculated by using the Tinivella method $[25,26]$. It is important to mention that an error is introduced because some assumptions about sediment property are required due to direct measurements lack.

The seafloor and BSR depth extracted from the depth seismic section is adopted to evaluate the regional geothermal gradient (GG), as described in [9]. Sensitive tests were performed to verify the reliability of the final velocity models, estimating an error of about $5 \%$ (e.g., [9]). The propagation of the error in depth is evaluated about $2 \%$. Finally, average 
percentage error of the gas hydrate and free gas concentrations was estimated about $1 \%$ and $2.5 \%$, respectively, as described by [9].

\section{The BSR}

The presence of gas hydrate, free gas and features related to them, such as the BSR, was recognized along the entire Chilean margin.

The most northern analyzed seismic line (RC2901-727), located at about $36^{\circ} \mathrm{S}$, shows a strong and continuous BSR [13]. Below it, it is possible to recognize a low velocity layer $(1380-1450 \mathrm{~m} / \mathrm{s})$ associated to free gas, showing the lowest velocity in the uplift section. Here, the GG, extracted from BSR depth, is about $87^{\circ} \mathrm{C} / \mathrm{km}$, and it decreases to $32^{\circ} \mathrm{C} / \mathrm{km}$ in the western part. This variable GG could explain the variable BSR depth (400 to $200 \mathrm{mbsf}$ ). This seismic line shows a strong variability in gas hydrate and free gas distributions. Highconcentration of gas hydrate (about $17 \%$ of total volume) is identified in western part of the line, while it is negligible in the uplift sector. The distribution of gas hydrate and free gas concentrations seems to have an opposite trend: in correspondence of high concentration of gas hydrate, low free gas concentration is present and vice versa. In fact, high concentration of free gas $(0.6 \%$ of total volume) is located in correspondence of uplift sector where the concentration of gas hydrate is negligible.

Moving south, offshore Arauco, the seismic line SO161-44, characterized by strong velocity variations, shows a high velocity layer $(1800-2000 \mathrm{~m} / \mathrm{s})$ above the BSR that it is associated with gas hydrates presence, while below it low velocity is recorded (about $1550 \mathrm{~m} / \mathrm{s}$ ) and associated to free gas [9]. It is possible to recognize a discontinuous BSR at a depth of $500 \mathrm{mbsf}$. The accretionary wedge is characterized by high concentration of gas hydrate (about $15 \%$ of total volume). In this sector, the GG is quite constant showing an average value of about $30^{\circ} \mathrm{C} / \mathrm{km}$.

North to Mocha Island, located at about $38.3^{\circ} \mathrm{S}$, two marine campaigns have been performed acquiring bathymetric data, seawater samples and marine sediments. The analysis of the acquired data allowed discovering a positive relief, composed by five aligned mud cones. The authors hypothesized that these features are located in proximity of the intersection of the theoretical gas hydrate stability zone with the seafloor where hydrates are not stable favouring flow escapes. This hypothesis is supported by the analysis of seismic lines located south to the Mocha Island and performed by [24]. The line SO16135 , at about $12 \mathrm{~km}$ south to the Mocha Island, shows a strong and continuous BSR showing a variable depth with a maximum thickness of about $200 \mathrm{mbsf}$ in the western portion.

Along the RC2901-731 seismic profile, located approximately $60 \mathrm{~km}$ south to the Mocha Island and direction NW-SE, it is possible to recognize a discontinuous and locally strong BSR. The BSR depth equal to about $250 \mathrm{mbsf}$ is quite constant from 4 to $16 \mathrm{~km}$ of distance, while in the other portions of the line, the BSR is weak or disappears. The BGR is recognized on both seismic lines with an average thickness of about $70 \mathrm{~m}$. In both sections, a drop in seismic velocity below the BSR is associated to the free gas presence, while high velocity (ranging from 1700 to $1900 \mathrm{~m} / \mathrm{s}$ ) is detected above BSR and associated with gas hydrates presence. In correspondence of the portion characterized by low velocity in both sections, it is possible to recognize faults and fractures with small slips affecting the seafloor. The eastern part of the seismic line SO161-35 show the presence of a submarine canyon. The average concentration of gas hydrate is about $7.5 \%$ of total volume in both sections. Also for these sections, an opposite trend in gas hydrate and free gas distribution was recognized. In fact, below high gas hydrate concentrations (ranging from 12 to $20 \%$ of total volume) it is present low free gas concentrations $(<0.4 \%$ of total volume for RC2901731 line and $<0.1 \%$ of total volume for SO161-35 line), while, locally, above high free gas concentrations (up to $1.1 \%$ of total volume for SO161-35 line and up to $0.3 \%$ of total 
volume for RC2901-731 line), low gas hydrate concentrations $(<4 \%$ of total volume in both sections) are present. Even if the GG has a variable trend along the seismic profiles, a higher GG (from 60 to $110^{\circ} \mathrm{C} / \mathrm{km}$ ) is identified in correspondence of SO161-35 section and a lower GG (from 35 to $65^{\circ} \mathrm{C} / \mathrm{km}$ ) was observed along the RC2901-731 section. The high free gas concentration in proximity of Mocha Island could be or relate to gas hydrate dissociation caused by past sliding processes reported by [37], or to free gas stored below an impermeable gas hydrate layer [14]. On the other hand, the lowest free gas concentration on the seismic line RC2901-731 cold be explained by a high fluid escape through faults and fractures, preventing free gas storing, associated to a limited a fluid supply from deep zones.

Moving south, the seismic profile SO161-29, located offshore Valdivia, shows the presence of many faults and fractures affecting the shallowest sediments confirming a high tectonic activity of this area [13]. This high tectonic activity could be the explanation for a weak and discontinuous BSR with a depth of about $550 \mathrm{mbsf}$ recognized along this line, allowing estimating a GG equal to $35^{\circ} \mathrm{C} / \mathrm{km}$. Two portions along the line (from 3 to $5 \mathrm{~km}$ and from 12 to $15 \mathrm{~km}$ ) show high concentration of gas hydrate ranging from 10 to $17 \%$ of total volume. Low seismic velocity below the seafloor suggests the presence of small concentration of free gas, while not free gas is recognized below the BSR because it was not possible to recognize the BGR. The absence of free gas could be related to the faults and fractures. Some faults and fractures above the BSR are characterized by low seismic velocity, which could be explained with a variation of porosity along the accretionary prism [13].

This seismic line SO161-40, located south to Chiloe Island, shows a strong and continuous BSR [12]. A strong and continuous reflector is recognised below the BSR, locally interpreted as BGR. The maximum depth of the BSR (about $600 \mathrm{mbs} f$ ) is identified in proximity of the boundary between the lower and upper continental slope where the estimated GG is about $25^{\circ} \mathrm{C} / \mathrm{km}$. Moving toward the upper slope, the BSR depth decreases due to an increase of GG reaching the valued of $45^{\circ} \mathrm{C} / \mathrm{km}$. The concentration of gas hydrate and free gas is variable along the seismic line, reaching the maximum value in the lower part of the upper slope. Here, the highest concentration of gas hydrate and the free gas is about 9.5 and $0.5 \%$ of total volume, respectively.

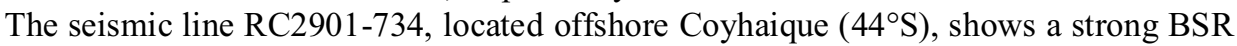
from the middle part of the accretionary prism to the first part of the fore arc basin [9-10]. The BSR depth is variable reaching maximum depth in correspondence of fore arc basin $(330 \mathrm{~m})$ and the accretionary prism $(250 \mathrm{~m})$, while the minimum depth $(130 \mathrm{~m})$ is in correspondence of structural high. The BSR is not present where there are intensive deformations with faults and fractures. Below BSR, a free gas layer is recognized with an average thickness of $70 \mathrm{~m}$ and associated to the presence of a BGR. The estimated GG, ranging from 95 to $10^{\circ} \mathrm{C} / \mathrm{km}$, can explain the variable BSR depth along the line. In fact, the maximum GG is in proximity of the structural high where the BSR depth is minimal. The fore arc basin is characterized by the highest gas hydrate concentration (about $23 \%$ of total volume), which becomes negligible in the proximity of the structural high. The concentration varies from 4 to $9 \%$ in the accretionary complex. The free gas concentration shows an opposite trend respect to the gas hydrate concentrations. In fact, the higher values (3\% of total volume) are recorded in correspondence of the structural high and decrease toward fore arc basin and accretionary prism (1\% of total volume). [9] supposed that structural high is a trap for the accumulation of fluid in the pore space. The seismic signal character suggests a strong variability in the sediments characteristics. The low velocity recorded above the BSR in correspondence of structural high can be explain with a porosity change and the seismic character suggests the presence of finer grained lithology. In the fore arc basin turbidite deposit could explain the seismic character, hypothesis in agreement with studies performed in the southern part [38]. The high velocity could be related to gas 
hydrate presence or change in petrophysical properties due to dewatering or uplift of the structural high.

Moving south to the Fuegian Triple Junction at about $320 \mathrm{~km}$, the seismic line RC2902790 was recently analysed to perform the first estimation of phase-gas in Patagonia [16]. High velocity was recognised above the BSR and could be associated to gas hydrate presence, while the seismic velocity $(1600-1700 \mathrm{~m} / \mathrm{s})$ below it is too high to justify free gas presence, but too low for water-bearing sediments (i.e., [39]. A possible explanation could be that these sediments host a mix of free gas and water and the real base of free gas is not detected. The average gas hydrate concentration is equal to about $3.4 \%$ of total volume with a maximum value of $10 \%$ of total volume, where the BSR is strongest.

Anyway, in this part of the Chilean margin, the presence of BSR was already supposed by other authors (e.g., [4, 7, 8]). The line IT95-171, located in proximity of the line RC2902-790, shows the presence of a continuous and high-amplitude BSR occurring from the forearc basin to the back-thrust [4]. Moving toward north, BSR disappears and is not recognised along the line IT97-251 located in proximity of the Fuegian Triple Junction. Clearly, the absence of the BSR does not exclude the gas hydrate presence.

\section{Theoretical modelling of gas hydrate stability vs. climate change}

Recently, the gas hydrate stability zone was modelled to identify the zone where exist the conditions for its stability along the Chilean margin (from Valparaiso to Taita Peninsula [40]) by using a steady state approach. The input data were collected in literature, as described in [40]. The GGs were estimated from the heat flow/thermal conductivity ratio considering the data published by [15]. Seafloor temperature and salinity water column were downloaded from the National Oceanographic Data Center website, while the water depth from the GMRT website. The gas composition was considered as pure methane on the basis of ODP Legs 141 and 202 [41-42]. This study allowed verifying where gas hydrate could be interesting by energy point of view, but also define the areas where gas hydrate are sensitive to climate change. In fact, different future scenarios based on the IPCC and NASA forecasts were considered to better understand the effects of climate change on gas hydrate stability. The modelling pointed out that at the present day the base of gas hydrate stability zone could be at $580 \mathrm{mbsf}$. In addition, climate change could strongly affect gas hydrate stability and, in particular, the increase in temperature would determine the gas hydrate dissociation along the upper slope.

\section{Conclusions}

The Chilean margin shows a strong variability in the distribution of gas hydrate and free gas concentration. This variability seems driven by an interaction between regional and local factors.

It is important to recall that the Chilean Margin is characterized by high seismicity, which could trigger slope failure and consequently affect gas hydrate stability. Clearly, the potential gas hydrate reservoir exploitation requires a deep knowledge of the natural and anthropogenic factors that could affect gas hydrate stability. Consequently, more effort should be devoted to gaining a better understanding of the relationship between the gas hydrate system and complex natural phenomena, such as climate change, slope stability and earthquakes. In this context, Chilean margin should be considered a natural laboratory to study the hydrate system evolution. 


\section{References}

1. Bangs, N.L., Sawyer, D.S., \& Golovchenko, X. (1993). Free gas at the base of the gas hydrate zone in the vicinity of the Chile triple junction. Geology, 2(1), 905-908. https://doi.org/10.1130/0091-7613(1993)021<0905:fgatbo $>2.3 . c 0 ; 2$

2. Brown, K.M., Bangs, N.L-, Froelich, P.N., \& Kvenvolden, K.A. (1996). The nature, distribution, and origin of gas hydrate in the Chile Triple Junction region. Earth and Planetary Science Letters, 139(3-4), 471-483. https://doi.org/10.1016/0012-821x(95)00243-6

3. Grevemeyer, I., Kaul, N., \& Díaz-Naveas, J.L. (2006). Geothermal evidence for fluid flow through the gas hydrate stability field off Central Chile-transient flow related to large subduction zone earthquakes? Geophysical Journal International, 166(1), 461-468. https://doi.org/10.1111/j.1365-246x.2006.02940.x

4. Loreto, M.F., Tinivella, U., \& Ranero, C.R. (2007). Evidence for fluid circulation, overpressure and tectonic style along the Southern Chilean margin. Tectonophysics, 429(3-4), 183-200. https://doi.org/10.1016/j.tecto.2006.09.016

5. Polonia, A., Brancolini, G., Torelli, L., \& Vera, E. (1999). Structural variability at the active continental margin off southernmost Chile. Journal of Geodynamics, 27(3), 289-307. https://doi.org/10.1016/s0264-3707(98)00003-9

6. Polonia, A., Brancolini, G., \& Torelli, L. (2001). The accretionary complex of southernmost Chile from the strait of Magellan to the Drake passage. Terra Antarctic, (8), 87-98.

7. Polonia, A., Torelli, L., Brancolini, G., \& Loreto, M.F. (2007). Tectonic accretion versus erosion along the southern Chile trench: oblique subduction and margin segmentation. Tectonics, 26(3), TC3005. https://doi.org/10.1029/2006tc001983

8. Polonia, A., \& Torelli, L. (2007). Antarctic/Scotia plate convergence off southernmost Chile. Geologica Acta, (5), 295-306.

9. Vargas-Cordero, I.C., Tinivella, U., Accaino, F., Loreto, M.F., Fanucci, F., \& Reichert, C. (2010) Analyses of bottom simulating reflections offshore Arauco and Coyhaique (Chile). Geo Marine Letters, 30(3-4), 271-281. https://doi.org/10.1007/s00367-009-0171-5

10. Vargas-Cordero, I., Tinivella, U., Accaino, F., Loreto, M.F.6 \& Fanucci, F. (2010). Thermal state and concentration of gas hydrate and free gas of Coyhaique Chilean Margin (44'30' S). Marine and Petroleum Geology, 27(5), 1148-1156. https://doi.org/10.1016/j.marpetgeo.2010.02.011

11. Vargas-Cordero, I., Tinivella, U., Accaino, F., Fanucci, F., Loreto, M.F., Lascano, M.E., \& Reichert, C. (2011). Basal and frontal accretion processes versus BSR characteristics along the Chilean margin. Journal of Geological Research, (2011), 1-10. https://doi.org/10.1155/2011/846101

12. Vargas Cordero, I., Tinivella, U., Villar Muñoz, L., \& Giustiniani, M. (2016). Gas hydrate and free gas estimation from seismic analysis offshore Chiloé island (Chile). Andean Geology, 43(3), 263-274. https://doi.org/10.5027/andgeov43n3-a02

13. Vargas-Cordero, I., Tinivella, U., \& Villar-Muñoz, L. (2017). Gas hydrate and free gas concentrations in two sites inside the Chilean margin (Itata and Valdivia Offshores). Energies, 10(12), 2154. https://doi.org/10.3390/en101221543

14. Vargas-Cordero, I., Tinivella, U., Villar-Muñoz, L., \& Bento, J. (2018). High gas hydrate and free gas concentrations: An explanation for seeps offshore South Mocha Island. Energies, 11(11), 3062. https://doi.org/10.3390/en11113062

15. Villar-Muñoz, L., Behrmann, J. H., Diaz-Naveas, J., Klaeschen, D., \& Karstens, J. (2013). Heat flow in the southern Chile forearc controlled by large-scale tectonic processes. Geo-Marine Letters, 34(2-3), 185-198. https://doi.org/10.1007/s00367-013-0353-z

16. Villar-Muñoz, L., Bento, J.P., Klaeschen, D., Tinivella, U., Vargas-Cordero, I. de la C., \& Behrmann, J.H. (2018). A first estimation of gas hydrates offshore Patagonia (Chile). Marine and Petroleum Geology, (96), 232-239. https://doi.org/10.1016/j.marpetgeo.2018.06.002 
17. Villar-Muñoz, L., Vargas-Cordero, I., Bento, J., Tinivella, U., Fernandoy, F., Giustiniani, M., \& Calderón-Díaz, S. (2019). Gas hydrate estimate in an area of deformation and high heat flow at the chile triple junction. Geosciences, 9(1), 28. https://doi.org/10.3390/geosciences9010028

18. Coffin, R., Pohlman, J., Gardner, J., Downer, R., Wood, W., Hamdan, L., \& Diaz, J. (2007). Methane hydrate exploration on the mid Chilean coast: A geochemical and geophysical survey. Journal of Petroleum Science and Engineering, 56(1-3), 32-41. https://doi.org/10.1016/j.petrol.2006.01.013

19. Geersen, J., Scholz, F., Linke, P., Schmidt, M., Lange, D., Behrmann, J.H., \& Hensen, C. (2016). Fault zone controlled seafloor methane seepage in the rupture area of the 2010 Maule earthquake, Central Chile. Geochemistry, Geophysics, Geosystems, 17(11), 4802-4813. https://doi.org/10.1002/2016gc006498

20. Jessen, G.L., Pantoja, S., Gutiérrez, M.A., Quiñones, R.A., González, R.R., Sellanes, J., \& Hinrichs, K.-U. (2011). Methane in shallow cold seeps at Mocha Island off central Chile. Continental Shelf Research, 31(6), 574-581. https://doi.org/10.1016/j.csr.2010.12.012

21. Sellanes, J., Quiroga, E., \& Gallardo, V.A. (2004). First direct evidence of methane seepage and associated chemosynthetic communities in the bathyal zone off Chile. Journal of the Marine Biological Association of the United Kingdom, 84(5), 1065-1066. https://doi.org/10.1017/s0025315404010422h

22. Sellanes, J., \& Krylova, E. (2005). A new species of Calyptogena (Bivalvia: Vesicomyidae) from a recently discovered methane seepage area off Concepción Bay, Chile $\left(\sim 36^{\circ} \mathrm{S}\right)$. Journal of the Marine Biological Association of the United Kingdom, 85(4), 969-976. https://doi.org/10.1017/s0025315405011963

23. Sellanes, J., Quiroga, E., \& Neira, C. (2008). Megafauna community structure and trophic relationships at the recently discovered Concepción Methane Seep Area, Chile, $\sim 36^{\circ}$ S. ICES Journal of Marine Science, 65(7), 1102-1111. https://doi.org/10.1093/icesjms/fsn099

24. Vargas-Cordero, I., Tinivella, U., Villar-Muñoz, L., Cárcamo, C., Bento, J. \& Giustiniani, M. (2018). Gas hydrate offshore Chilean margin. FIERY ICE 2018. Southwest Petroleum University, Chengdu, China (October 31 - November 3).

25. Tinivella, U. (1999). A method for estimating gas hydrate and free gas concentrations in marine sediments. Boll Geofis Teorica Applicata, (40), 19-30.

26. Tinivella, U. (2002). The seismic response to overpressure versus gas hydrate and free gas concentration. Journal of Seismic Exploration, (11), 283-305.

27. Cisternas, M., Atwater, B.F., Torrejón, F., Sawai, Y., Machuca, G., Lagos, M., \& Husni, M. (2005). Predecessors of the giant 1960 Chile earthquake. Nature, 437(7057), 404-407. https://doi.org/10.1038/nature03943

28. Forsyth, D.W. (1975). Fault plane solutions and tectonics of the South Atlantic and Scotia Sea. Journal of Geophysical Research, 80(11), 1429-1443. https://doi.org/10.1029/jb080i011p01429

29. Cunningham, W.D. (1993). Strike-slip faults in the southernmost andes and the development of the Patagonian orocline. Tectonics, 12(1), 169-186. https://doi.org/10.1029/92tc01790

30. Bangs, N.L., \& Cande, S.C. (1997). Episodic development of a convergent margin inferred from structures and processes along the southern Chile margin. Tectonics, 16(3), 489-503. https://doi.org/10.1029/97tc00494

31. Ramos, V.A. (1999). Plate tectonic setting of the Andean Cordillera. Episodes, 22(3), 183-190. https://doi.org/10.18814/epiiugs/1999/v22i3/005

32. Grevemeyer, I., Diaz-Naveas, J.L., Ranero, C.R., \& Villinger, H.W. (2003). Heat flow over the descending Nazca plate in central Chile, $32^{\circ} \mathrm{S}$ to $41^{\circ} \mathrm{S}$ : observations from ODP Leg 202 and the occurrence of natural gas hydrates. Earth and Planetary Science Letters, 213(3-4), 285-298. https://doi.org/10.1016/s0012-821x(03)00303-0

33. Melnick, D. (2007). Neogene seismotectonics of the South-Central Chile Margin: Subductionrelated processes over various temporal and spatial scales. Ph.D. Thesis. Potsdam, Germany: Universität Potsdam. 
34. Cembrano, J., \& Lara, L. (2009). The link between volcanism and tectonics in the southern volcanic zone of the Chilean Andes: A review. Tectonophysics, 471(1-2), 96-113. https://doi.org/10.1016/j.tecto.2009.02.038

35. Vargas Cordero, I. (2009). Gas hydrate occurrence and morphostructures along Chilean margin. $\mathrm{Ph} . \mathrm{D}$. Thesis. Trieste, Italy: University of Trieste.

36. Manea, V. C., Pérez-Gussinyé, M., \& Manea, M. (2012). Chilean flat slab subduction controlled by overriding plate thickness and trench rollback. Geology, 40(1), 35-38. https://doi.org/10.1130/g32543.1

37. Geersen, J., Völker, D., Behrmann, J.H., Reichert, C., \& Krastel, S. (2011). Pleistocene giant slope failures offshore Arauco Peninsula, Southern Chile. Journal of the Geological Society, 168(6), 1237-1248. https://doi.org/10.1144/0016-76492011-027

38. Marsaglia, K.M., Torrez, X.V., Padilla, I., \& Rimkus, K.C. (1995). Provenance of Pleistocene and Pliocene sand and sandstone, ODP leg 141, Chile margin. In Proceedings of the Ocean Drilling Program. Scientific Results, (141), 133-151. Lewis, S.D., Behrmann, J.H., Musgrave, R.J., Cande, S.C. (Eds.). https://doi.org/10.2973/odp.proc.sr.141.005.1995

39. Tinivella, U., \& Carcione, J.M. (2001). Estimation of gas-hydrate concentration and free-gas saturation from $\log$ and seismic data. The Leading Edge, 20(2), 200-203. https://doi.org/10.1190/1.1438914

40. Alessandrini, G., Tinivella, U., Giustiniani, M., de la Cruz Vargas-Cordero, I., \& Castellaro, S. (2019). Potential instability of gas hydrates along the Chilean Margin due to ocean warming. Geosciences, 9(5), 234. https://doi.org/10.3390/geosciences9050234

41. Bangs, N.L., \& Brown, K.M. (1995). Regional heat flow in the vicinity of the Chile Triple Junction constrained by the depth of the bottom simulating reflector. Proceedings of the Ocean Drilling Program, (141), 253-258. https://doi.org/10.2973/odp.proc.sr.141.043.1995

42. Mix, A.C., Tiedemann, R., Blum, P. \& Shipboard Scientific Party Proceedings of the ODP (2003). Initial Reports; Ocean Drilling Program: College Station. Ostin, Texas, United States. 